\title{
Hydrochemical evaluation of river water quality—a case study
}

\author{
Afishin Qishlaqi $^{1} \cdot$ Sediqeh Kordian $^{1} \cdot$ Abbas Parsaie $^{2}$
}

Received: 3 December 2015/Accepted: 31 March 2016/Published online: 13 April 2016

(C) The Author(s) 2016. This article is published with open access at Springerlink.com

\begin{abstract}
Rivers are one of the most environmentally vulnerable sources for contamination. Since the rivers pass through the cities, industrial and agricultural centers, these have been considered as place to dispose the sewages. This issue is more important when the river is one of the main sources of water supplying for drinking, agricultural and industrial utilizations. The goal of the present study was assessing the physicochemical characteristics of the Tireh River water. The Tireh River is the main river in the Karkheh catchment in the Iran. To this end, 14 sampling stations for measuring the physicochemical properties of Tireh River along the two main cities (Borujerd and Dorud) were measured. The results showed that (except $\left.\mathrm{SO}_{4}\right) \mathrm{Mg}$, $\mathrm{Ca}$ and other anions and cations have concentrations under WHO standard limitation. Almost all samples have suitable conditions for drinking with regard to the WHO standard and in comparison with agricultural standard (FAO Standard), and the potential of water is suitable for irrigation purposes. According to Wilcox diagram, $78 \%$ of samples were at the $\mathrm{C} 3-\mathrm{S} 1$ and $21.5 \%$ were at $\mathrm{C} 2-\mathrm{S} 1$ classes. The piper diagram shows that most of samples are bicarbonate and calcic facies.
\end{abstract}

Abbas Parsaie

Abbas_Parsaie@yahoo.com

Afishin Qishlaqi

qishlaqi@shahroodut.ac.ir

Sediqeh Kordian

Kordian_S@yahoo.com

1 Environmental Geology Department, Geology College, Shahrood University, Shahrud, Semnan Province, Iran

2 Hydro Structure, Lorestan University, Khorramabad, Iran
Keywords Tireh River - Water quality $\cdot$ Hydrochemistry · WHO standard

\section{Introduction}

Water quality is an important factor for improving the level of public human health projects. Continuous monitoring of the water quality is one of the important activities of environmentalists, so to this end, governments have constructed sampling stations along the rivers, especially rivers which pass through the cities, agriculture and industrial centers (Benedini and Tsakiris 2013a, b; Boyd 2015; Noori et al. 2011a, b; Wang et al. 2015; Zarei and Pourreza Bilondi 2013). Unfortunately, most of the times, rives are considered as places to dispose the sewage (Benedini and Tsakiris 2013a, b). Study on water quality of rivers including the hydrochemical parameter, heavy metal contamination and bacterial infections is a basic factor for developing the water resource management projects ( $\mathrm{Ji}$ 2008; Moasheri et al. 2013; WHO 2011; Zare Abyaneh 2014). Several scientific reports about the condition of water quality of surface waters all around the world have been published (Najafzadeh and Tafarojnoruz 2016; Najafzadeh and Zahiri 2015; Noori et al. 2011a, b). Merrikhpour and Jalali (2015) studied the hydrochemical and heavy metal concentration in the soil and water resources of Hamadan province of Iran. They measured the concentration of cadmium $(\mathrm{Cd})$, copper $(\mathrm{Cu})$, lead $(\mathrm{Pb})$ and zinc $(\mathrm{Zn})$ as important parameters for developing the agricultural development projects. Finally, they stated that the values of these parameters are under standard indices, and the potential of studied area is suitable for developing the agricultural projects. Recently, by advancing the soft computing techniques in the field of water quality 
modeling (Najafzadeh et al. 2016), in addition to field studies, investigators try to use these techniques such as artificial neural network and support vector machine for predicting and classifying the river water quality parameters (Noori et al. 2015, 2016; Parsaie and Haghiabi 2015a, b, c; Parsaie et al. 2015; Singh et al. 2009). Noori et al. (2010) measured the concentration of BOD5, COD, EC, $\mathrm{NO}_{3}{ }^{-}, \mathrm{SO}_{4}{ }^{2-}$, temperature, $\mathrm{Cl}^{-}, \mathrm{DO}$, hardness, TDS, $\mathrm{pH}$, and turbidity as Karoon River water quality parameters and used the multivariate statistical analysis and principal component analysis (PCA) technique for determining the relationship between the parameters. They stated that EC and TDS were two dominant physical parameters in all canonical variates. It is notable that the field studies of river water quality are principle for the development of water projects and soft computing models. Therefore, in this paper, the water quality parameters of Tireh River (Lorestan Province, Iran) including the $\mathrm{Na}, \mathrm{K}, \mathrm{Ca}, \mathrm{Mg}, \mathrm{Cl}, \mathrm{SO}_{4}$, $\mathrm{HCO}_{3}$, TDS, EC and $\mathrm{pH}$ were measured, and for this purpose, a field study was programmed.

\section{Site description and data}

The Tireh River is one of the main rivers at the Lorestan province (Iran). This river passes through two main cities of the Lorestan province (Dorud and Borujerd) and it is one of the main affluent rivers in the DEZ catchment in Iran; Fig. 1 shows the Tireh River location in Iran. Geological structure of the studied area includes igneous and metamorphic rocks (belongs to Sanandaj zone) and sedimentary rocks (belongs to Zagros Mountains). The geological structure of the studied area is shown in Fig. 1. To evaluate the water quality of Tireh River, 14 sampling stations as shown in Fig. 1 are considered along the river. As shown in Fig. 1, the triangular symbols are considered for sampling stations. The temperature $(T), \mathrm{pH}$, specific conductivity (EC), bicarbonate $\left(\mathrm{HCO}_{3}{ }^{-}\right)$, sulfates $\left(\mathrm{SO}_{4}{ }^{2-}\right)$, chlorides (Cl), sodium $\left(\mathrm{Na}^{+}\right)$, magnesium $\left(\mathrm{mg}^{2+}\right)$, calcium $\left(\mathrm{Ca}^{2+}\right)$, nitrates $\left(\mathrm{NO}_{3}{ }^{-}\right)$and discharge $(Q)$ were measured along the river.

\section{Results and discussion}

Natural contaminants play an important role in river water quality. Vacating the pollutions which have anthropogenic sources in rivers because of growing urbanization and development of industrial near rivers rapidly decreases the quality of river water. The water quality of river introduces its potential to use in agriculture for defining the cropping pattern and in industrials to develop the type of industry. Water quality is defined using numbers of physical and chemical parameters. Pollution decreases the water quality under the standard limitations. In this paper, the water quality of Tireh River was evaluated for drinking, agricultural and industrial usages. The values of physical and chemical parameters are measured and shown in Table 1. To evaluate the potential of water quality for mentioned usages, the Piper, Scholler and Wilcox diagrams were plotted.

$\mathrm{pH}$ of natural waters due to geological factors as well as biological activity usually is alkaline or slightly acidic. As shown in Fig. 2, the value of $\mathrm{pH}$ varies between 7.89 and 8.90. Therefore, almost all samples are alkaline. Department of environment Islamic republic of Iran (DERI) proposed a range between 6.5 and 8.5 as standard limitation for drinking usages. As shown in Fig. 2, two samples are less than the standard limitation. This reduction is because of injecting the sewages of Dorud and Borujerd.

Electrical conductivity as important water quality parameters shows the ability of electrical current in the water. This parameter is a function of the presence of ions and has direct relationship to the total dissolved solids (TDS). By increasing the amount of sulfate, chloride, sodium, potassium, calcium and magnesium in water, the EC is increased; therefore, the water quality is decreased. The DERI has proposed the $600 \mu \mathrm{s} / \mathrm{cm}$ for the upper standard limitation for irrigation usages. The value of EC along the Tireh River is shown in Fig. 3. The value of EC was measured between 445 and $1434 \mu \mathrm{s} / \mathrm{cm}$ and rapidly increasing the value of EC at station 12 is because of injecting the industrial sewage in Tireh River.

\section{Cation concentration}

Figure 4 shows the value of cation concentrations $\left(\mathrm{K}^{+}\right.$, $\mathrm{Na}^{+}, \mathrm{Mg}^{2+}$ and $\mathrm{Ca}^{2+}$ ) at each sampling station. Sodium concentration in water samples was measured between 2.76 and $104.42 \mathrm{mg} / \mathrm{l}$ (mean $53.34 \mathrm{ppm}$ ). Compression of the observed values with Iran Standard Institute limitation $(200 \mathrm{mg} / \mathrm{l})$ shows that the values of sodium concentration in all the sampling stations are under the standard limitation. Increasing the concentration of sodium at the end stations (12 and 13) is because of fine clay minerals in sediment of Tireh River and Dorud city sewage located at the station (12 and 13) water which is injected in the Tireh River. Also mild slope of river helps to dissolve evaporated minerals, especially halite and provides ion exchange process.

The concentrations of magnesium as shown in Fig. 4 change between 27.9 and $157.95 \mathrm{mg} / \mathrm{l}$ (mean value $61.78 \mathrm{mg} / \mathrm{l}$ for all the sampling stations). High levels of magnesium concentration are usually deposited as magnesium carbonate and magnesium hydroxide and only in 


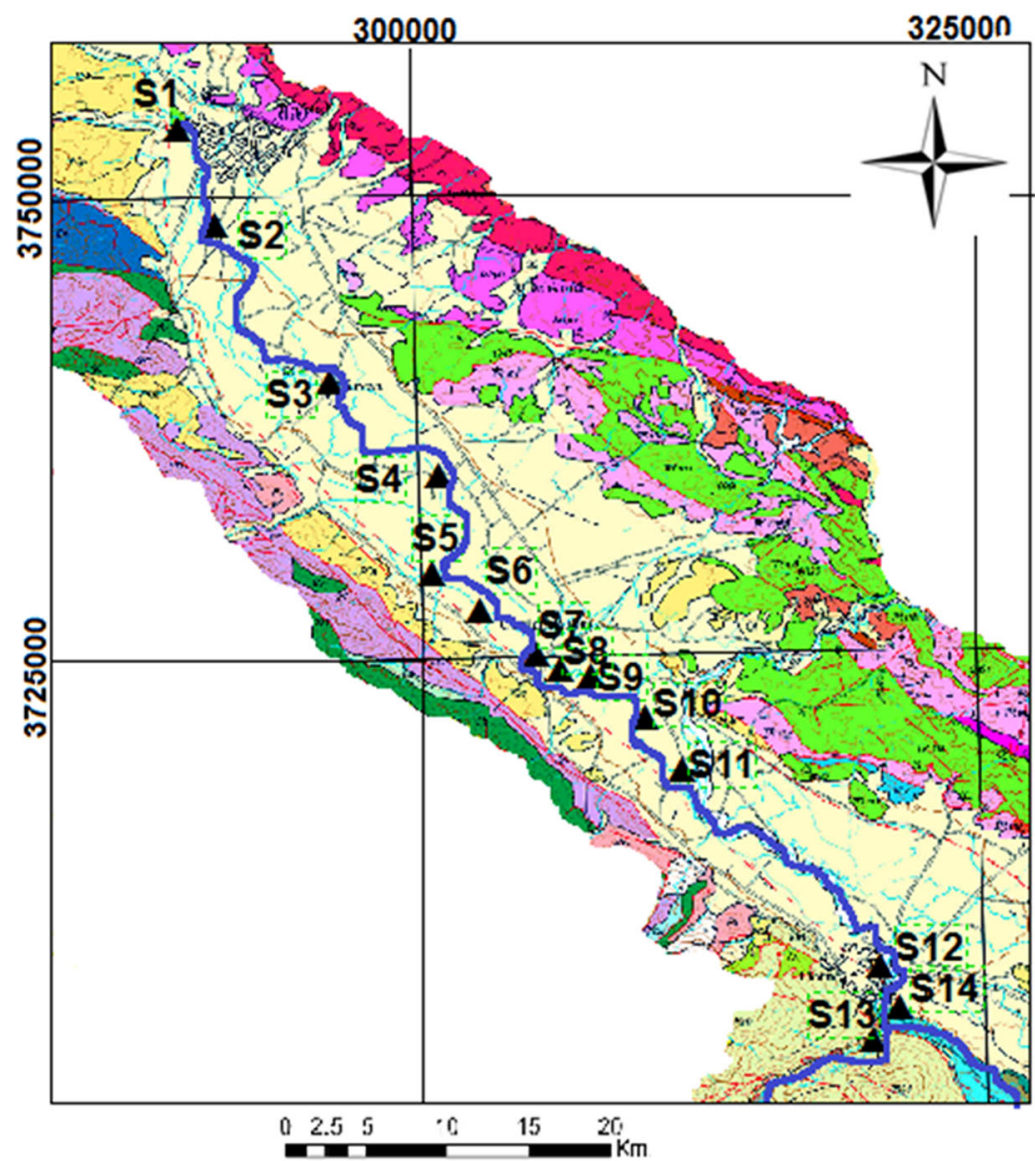

CONVENTIONAL SYMBOLS

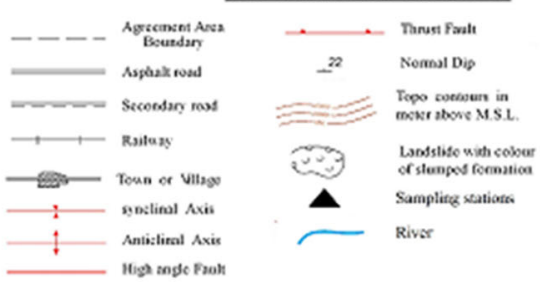

Geological Legend

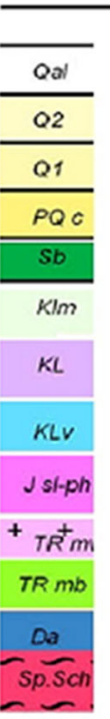

Gal : Recent alluvius

Q2: Young and low level tenaces

Q1: Old and high level termaces

PQ $\mathrm{c}$ : Conglomerate intercalations of zandztone and cl: Sb : Limestone , dolonite , shale ( Alahbazan formation KIm : Dark grey limestone and narl

KI. Thick bedded to massive limctone and dolomitic CLv: Thick bedded to massive limestone and volcauic: I sl-ph : Dark grey slate and plydlite with intercalations fine grain saud stone and localy linestone TR mv: Meta volcanic and phyllite with intercalation ! TR mb : Meta limextone and dolomite with intercalatio Da : Dark Gray Limestone, Dolomitic Limertone and I Schist . Spotted sclist Andalusite sclist

Fig. 1 The GIS picture of the Tireh River and its catchment boundaries

Table 1 Water quality parameters measured by authors

\begin{tabular}{|c|c|c|c|c|c|c|c|c|c|c|}
\hline Stations & $\begin{array}{l}\text { EC } \\
(\mu \mathrm{moh} / \mathrm{cm})\end{array}$ & $\begin{array}{l}\text { T.D.S } \\
(\mathrm{mg} / \mathrm{L})\end{array}$ & $\mathrm{PH}$ & $\begin{array}{l}\mathrm{Ca}^{2+} \\
(\mathrm{mg} / \mathrm{L})\end{array}$ & $\begin{array}{l}\mathrm{Mg}^{2+} \\
(\mathrm{mg} / \mathrm{L})\end{array}$ & $\begin{array}{l}\mathrm{Na}^{+} \\
(\mathrm{mg} / \mathrm{L})\end{array}$ & $\begin{array}{l}\mathrm{K}^{+} \\
(\mathrm{mg} / \mathrm{L})\end{array}$ & $\begin{array}{l}\mathrm{HCO}_{3}^{-} \\
(\mathrm{mg} / \mathrm{L})\end{array}$ & $\begin{array}{l}\mathrm{Cl}^{-} \\
(\mathrm{mg} / \mathrm{L})\end{array}$ & $\begin{array}{l}\mathrm{SO}_{4}^{2-} \\
(\mathrm{mg} / \mathrm{L})\end{array}$ \\
\hline S01 & 680 & 506.53 & 7.95 & 4.5 & 2.0 & 0.04 & 0.04 & 5.0 & 1.25 & 0.67 \\
\hline S02 & 815 & 617.46 & 7.85 & 5.5 & 2.0 & 1.07 & 0.05 & 5.5 & 2.00 & 1.05 \\
\hline S03 & 942 & 677.46 & 7.58 & 5.2 & 1.8 & 2.7 & 0.05 & 5.0 & 3.50 & 1.22 \\
\hline S04 & 933 & 684.98 & 7.85 & 5.5 & 1.5 & 2.6 & 0.05 & 5.5 & 3.35 & 0.85 \\
\hline S05 & 925 & 656.95 & 7.85 & 7.4 & 2.1 & 2.65 & 0.05 & 5.0 & 3.50 & 0.95 \\
\hline S06 & 537 & 419.61 & 7.95 & 3.8 & 1.7 & 0.12 & 0.03 & 4.5 & 0.45 & 0.60 \\
\hline S07 & 905 & 678.55 & 7.78 & 4.8 & 2.0 & 2.85 & 0.05 & 5.5 & 3.30 & 0.80 \\
\hline S08 & 918 & 648.47 & 7.73 & 4.7 & 2.1 & 2.5 & 0.05 & 5.0 & 3.25 & 1.03 \\
\hline S09 & 905 & 627.83 & 7.85 & 1.65 & 5.0 & 2.7 & 0.05 & 5.0 & 3.25 & 1.05 \\
\hline S10 & 858 & 582.1 & 7.68 & 2.25 & 3.75 & 2.78 & 0.04 & 4.5 & 3.00 & 0.95 \\
\hline S11 & 867 & 601.76 & 7.38 & 2.75 & 3.6 & 2.58 & 0.04 & 4.0 & 3.00 & 1.92 \\
\hline S12 & 1366 & 1109.79 & 7.44 & 4.5 & 6.5 & 4.54 & 0.08 & 7.5 & 2.50 & 6.00 \\
\hline S13 & 1037 & 773.76 & 7.51 & 3.7 & 2.8 & 4.39 & 0.06 & 5.5 & 3.70 & 2.00 \\
\hline S14 & 483 & 348.3 & 8.25 & 3.0 & 1.2 & 0.58 & 0.02 & 3.0 & 1.00 & 0.86 \\
\hline
\end{tabular}

very alkaline conditions soluble in water. EPA (2009) proposed a $50 \mathrm{ppm}$ for upper limitation for the concentration of magnesium and also department of environment
Islamic republic of Iran (DERI) has defined the $150 \mathrm{ppm}$ as upper limitation for concentration of magnesium for the agricultural usage. Comparison of the value of measured 


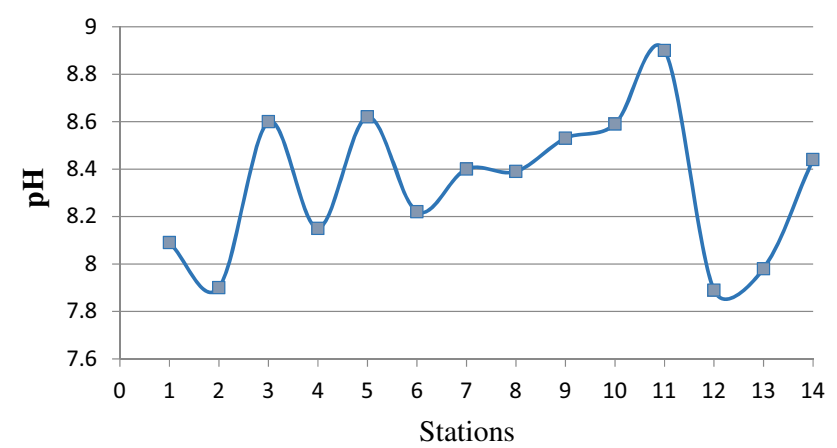

Fig. 2 Variation of $\mathrm{pH}$ along the Tireh River

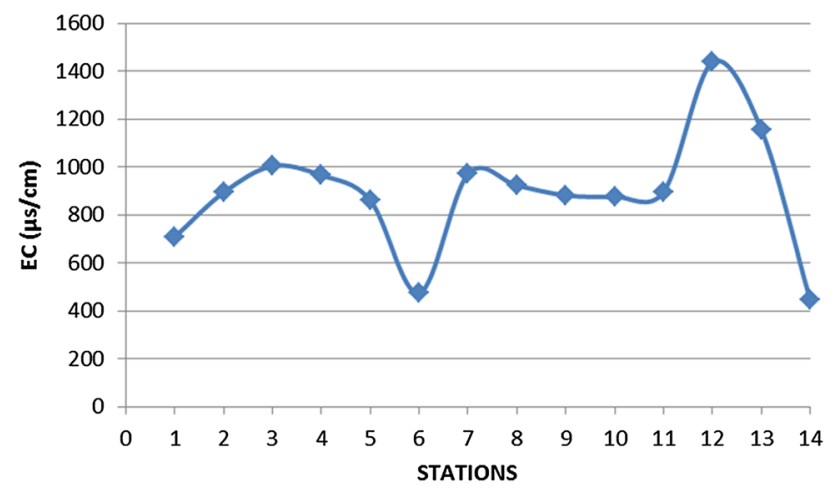

Fig. 3 Variation of EC along the Tireh River

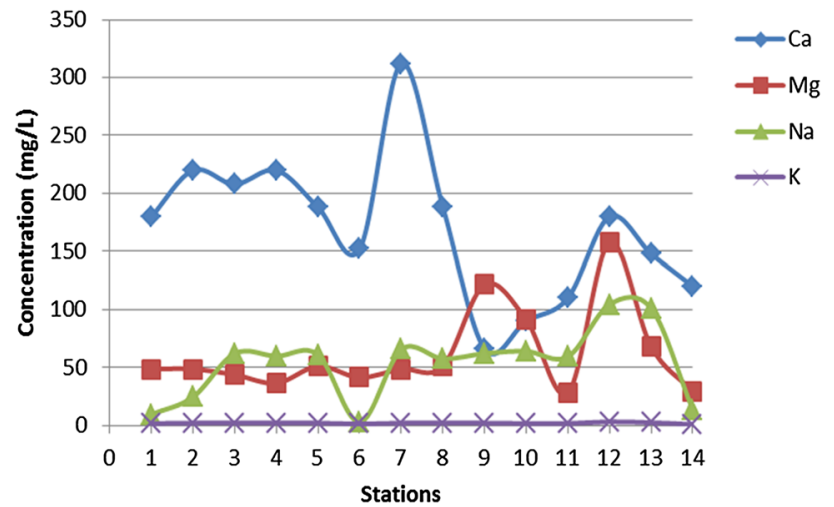

Fig. 4 The concentration of the cations along the Tireh River

data with the standard limitations found that the sixth station has value more than the EPA standard. Station 12 which has been heavily influenced by sewage of Dorud has a value higher than allowed for agriculture (irrigation) usage. The concentration of calcium as shown in Fig. 4 is between 66 and $312 \mathrm{ppm}$ (mean $169.71 \mathrm{ppm}$ ). With regard to the DERI standard, the upper limitation of the calcium concentration for irrigation usages is equal to $200 \mathrm{ppm}$; therefore, four stations are more than the standard limitations. As shown in Fig. 4, the highest value is related to

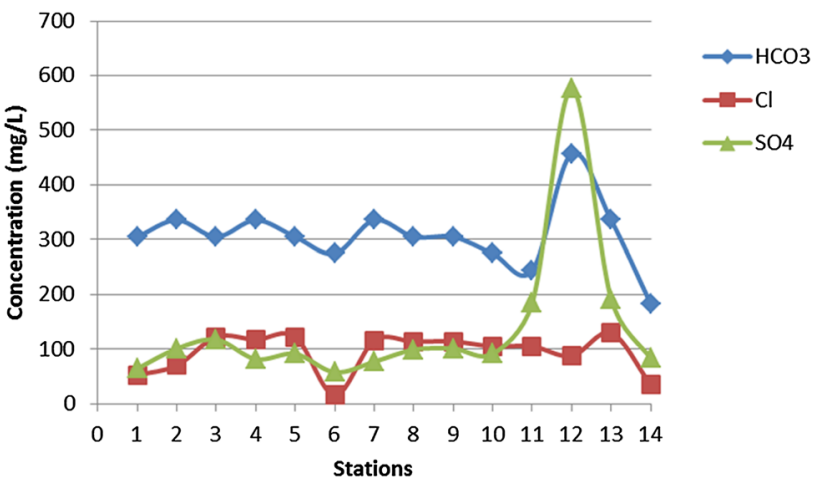

Fig. 5 The concentration of anions in the Tireh River

station 7. The main source of the calcium is dissolution of limestone and minerals such as dolomite and gypsum in river. The concentration of potassium as presented in Fig. 4 varies between 1.17 and $3.12 \mathrm{mg} / \mathrm{l}$ (mean $1.83 \mathrm{ppm}$ ). There is no standard for this parameter.

\section{Anion concentration}

The concentrations of anions are shown in Fig. 5. Figure 5 shows the values of anions including chlorine, sulfate and bicarbonate along the Tireh River. The concentration of chlorine as shown in Fig. 5 varies between 15.75 and $129.5 \mathrm{ppm}$ (mean $93.25 \mathrm{ppm}$ ) along the Tireh River. World Health Organization (WHO 2011) proposed the $250 \mathrm{ppm}$ for upper limitation of concentration of chlorine in drinking water; therefore, all concentration values of chlorine for all sampling stations are under WHO standard limitation. An Iran agricultural water standard also has proposed the $600 \mathrm{ppm}$ of the chlorine concentration for the irrigation usages. Therefore, all the samples are suitable condition for drinking and irrigation usages. The highest value of the chlorine concentration is related to the stations 12 and 13 strongly influenced by sewage of Dorud city.

The concentration of sulfate as shown in Fig. 5 varies between 57.6 and $576 \mathrm{ppm}$ (mean $136.8 \mathrm{ppm}$ ). The main source of the sulfate in addition to the neural pollutions is injecting the industrial sewages. WHO (2011) proposed the $250 \mathrm{ppm}$ as upper limitation for the sulfate concentration of drinking water. With regard to the WHO standard, except station 12 which is forcefully influenced by Dorud city sewage, other samples have suitable condition. As shown in Fig. 5, the concentration of Bicarbonate changes between 183 and 457.5 ppm (mean 307.17 ppm). Apparently erosion and dissolution of limestone deposits take place in the river, as well as urban and rural sewage discharge such as Dorud sewage especially due to the arrival 
Table 2 Facies and sequence of anions and cations of main water resources

\begin{tabular}{|c|c|c|c|}
\hline Sample number & Sample facies & Concentration (anions) & Concentration (cations) \\
\hline 1 & Calcium bicarbonate & $\mathrm{Ca}>\mathrm{Mg}>\mathrm{Na}+\mathrm{K}$ & $\mathrm{HCO}_{3}>\mathrm{Cl}>\mathrm{SO}_{4}$ \\
\hline 2 & Calcium bicarbonate & $\mathrm{Ca}>\mathrm{Mg}>\mathrm{Na}+\mathrm{K}$ & $\mathrm{HCO}_{3}>\mathrm{Cl}>\mathrm{SO}_{4}$ \\
\hline 3 & Calcium bicarbonate & $\mathrm{Ca}>\mathrm{Na}+\mathrm{K}>\mathrm{Mg}$ & $\mathrm{HCO}_{3}>\mathrm{Cl}>\mathrm{SO}_{4}$ \\
\hline 4 & Calcium bicarbonate & $\mathrm{Ca}>\mathrm{Na}+\mathrm{K}>\mathrm{Mg}$ & $\mathrm{HCO}_{3}>\mathrm{Cl}>\mathrm{SO}_{4}$ \\
\hline 5 & Calcium bicarbonate & $\mathrm{Ca}>\mathrm{Na}+\mathrm{K}>\mathrm{Mg}$ & $\mathrm{HCO}_{3}>\mathrm{Cl}>\mathrm{SO}_{4}$ \\
\hline 6 & Calcium bicarbonate & $\mathrm{Ca}>\mathrm{Mg}>\mathrm{Na}+\mathrm{K}$ & $\mathrm{HCO}_{3}>\mathrm{SO}_{4}>\mathrm{Cl}$ \\
\hline 7 & Calcium bicarbonate & $\mathrm{Ca}>\mathrm{Na}+\mathrm{K}>\mathrm{Mg}$ & $\mathrm{HCO}_{3}>\mathrm{Cl}>\mathrm{SO}_{4}$ \\
\hline 8 & Calcium bicarbonate & $\mathrm{Ca}>\mathrm{Na}+\mathrm{K}>\mathrm{Mg}$ & $\mathrm{HCO}_{3}>\mathrm{Cl}>\mathrm{SO}_{4}$ \\
\hline 9 & Magnesium bicarbonate & $\mathrm{Mg}>\mathrm{Na}+\mathrm{K}>\mathrm{Ca}$ & $\mathrm{HCO}_{3}>\mathrm{Cl}>\mathrm{SO}_{4}$ \\
\hline 10 & Magnesium bicarbonate & $\mathrm{Mg}>\mathrm{Na}+\mathrm{K}>\mathrm{Ca}$ & $\mathrm{HCO}_{3}>\mathrm{Cl}>\mathrm{SO}_{4}$ \\
\hline 11 & Magnesium bicarbonate & $\mathrm{Mg}>\mathrm{Ca}>\mathrm{Na}+\mathrm{K}$ & $\mathrm{HCO}_{3}>\mathrm{Cl}>\mathrm{SO}_{4}$ \\
\hline 12 & Magnesium bicarbonate & $\mathrm{Mg}>\mathrm{Na}+\mathrm{K}>\mathrm{Ca}$ & $\mathrm{SO}_{4}>\mathrm{HCO}_{3}>\mathrm{Cl}$ \\
\hline 13 & Calcium bicarbonate & $\mathrm{Na}+\mathrm{K}>\mathrm{Ca}>\mathrm{Mg}$ & $\mathrm{HCO}_{3}>\mathrm{Cl}>\mathrm{SO}_{4}$ \\
\hline 14 & Calcium bicarbonate & $\mathrm{Ca}>\mathrm{Mg}>\mathrm{Na}+\mathrm{K}$ & $\mathrm{HCO}_{3}>\mathrm{Cl}>\mathrm{SO}_{4}$ \\
\hline
\end{tabular}

of bicarbonate ion in the water. Oxidation of organic matter in the wastewater produces $\mathrm{CO}_{2}$ that leads to $\mathrm{pH}$ reduction. Reduction of $\mathrm{pH}$ helps in the dissolution of carbonate minerals.

\section{Classification and hydrochemical facies of samples}

Piper diagram is a graph uses for evaluating the hydrochemical properties of water quality. In this graph, the facies of water were defined using the cation property. The results of assessing the hydrochemical facies of samples are shown in Table 2 and Fig. 6. Plotting the chemical data on the piper diagram shows that except samples 9 and 10 which are magnesium bicarbonate and sample 12 which is sulfate-magnesium, the facies of other samples are bicarbonate-calcium. Erosion and dissolution of limestone deposits that are exposed in the study area are due to the entry of calcium ions and bicarbonate solution into water. Changing the facies of water samples from the calcium bicarbonate to the magnesium bicarbonate is because of injecting the Dorud sewage in the Tireh River. By the time the river leaves the city, facies of water samples return to the original type (bicarbonates-calcic) at stations 13 and 14.

\section{Wilcox diagrams}

Wilcox diagram is used to assess the potential of water quality for irrigation usages. This graph is based on two parameters: EC (according to micro-Mohs/cm) and sodium adsorption ratio (SAR). In this diagram, EC as a risk of salinity and SAR as risk of alkalinity are considered. In Wilcox diagram, $C$ represents the salinity and $S$ represents

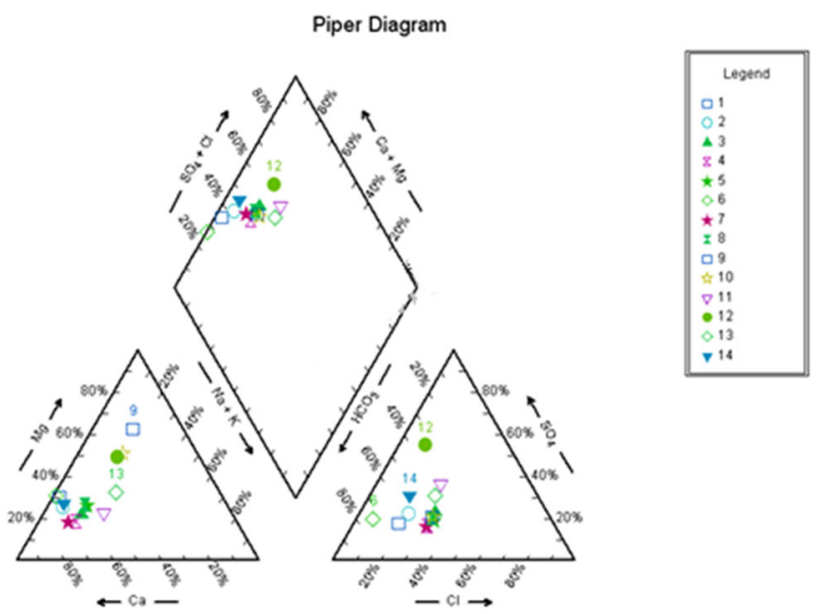

Fig. 6 Piper diagram for river water samples

the SAR. Figure 7 shows the results of plotting the river water quality of Tireh River on Wilcox diagram. As seen from Fig. 7, more than $78 \%$ are classified as C3-S1. These results show that the water quality by applying some necessary measures is suitable for irrigation. Other samples are classified as $\mathrm{C} 2-\mathrm{S} 1$ in the Wilcox diagram. The C2-S1 class shows the suitable potential of water for irrigation usages.

\section{Conclusion}

Rivers are one of the main sources of water supply for drinking, agricultural and industrial usages. Therefore, controlling the quality of rivers is important, since the water quality of the rivers is directly related to human and environment health. Unfortunately, sometimes it seems 


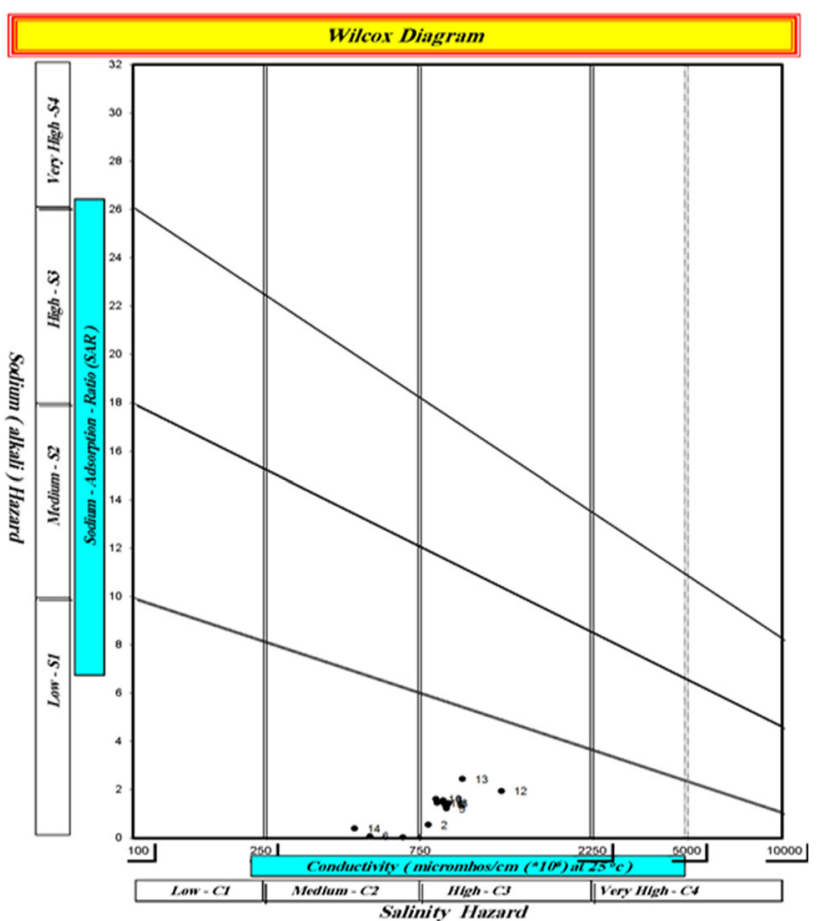

Fig. 7 Wilcox diagram to evaluate water use for agricultural purposes

that river has been considered a place for injection of sewages. Assessing the water quality is an important parameter for developing the industrial and agricultural projects. In this study, the water quality of Tireh River was evaluated by measuring the hydrochemical parameters. The result shows that the water quality of Tireh River is suitable for developing the agricultural projects. Observing the value of hydrochemical parameters found that injecting industrial sewages in the Tireh River of Dorud city leads to strong pollution, especially around the Dorud city.

Open Access This article is distributed under the terms of the Creative Commons Attribution 4.0 International License (http:// creativecommons.org/licenses/by/4.0/), which permits unrestricted use, distribution, and reproduction in any medium, provided you give appropriate credit to the original author(s) and the source, provide a link to the Creative Commons license, and indicate if changes were made.

\section{References}

Benedini M, Tsakiris G (2013a) Water quality in the context of water resources management. Water quality modelling for rivers and streams. Springer, Netherlands, pp 1-9

Benedini M, Tsakiris G (2013b) Water quality modelling for rivers and streams. Springer Science and Business Media, Berlin

Boyd CE (2015) Water quality: an introduction. Springer International Publishing, Switzerland

EPA U (2009) National recommended water quality criteria. United States Environmental Protection Agency, Office of Water, Office of Science and Technology
Ji Z-G (2008) Hydrodynamics and water quality: modeling rivers, lakes, and estuaries. Wiley, New York

Merrikhpour H, Jalali M (2015) Geostatistical assessment of solidliquid distribution coefficients $(\mathrm{K} \mathrm{d})$ for $\mathrm{Cd}, \mathrm{Cu}, \mathrm{Pb}$ and $\mathrm{Zn}$ in surface soils of Hamedan, Iran. Model Earth Syst Environ 1(4):1-9

Moasheri SA, Shams Goshki A, Parsaie A (2013) "SAR" qualities parameter persistence by a compound method of geostatic and artificial neural network (case study of Jiroft plain). Int J Agric Crop Sci 6:157-166

Najafzadeh M, Tafarojnoruz A (2016) Evaluation of neuro-fuzzy GMDH-based particle swarm optimization to predict longitudinal dispersion coefficient in rivers. Environ Earth Sci 75(2):1-12

Najafzadeh M, Zahiri A (2015) Neuro-fuzzy GMDH-based evolutionary algorithms to predict flow discharge in straight compound channels. J Hydrol Eng 20(12):04015035

Najafzadeh M, Etemad-Shahidi A, Lim SY (2016) Scour prediction in long contractions using ANFIS and SVM. Ocean Eng 111:128-135

Noori R, Sabahi MS, Karbassi AR, Baghvand A, Taati Zadeh H (2010) Multivariate statistical analysis of surface water quality based on correlations and variations in the data set. Desalination 260(1-3):129-136

Noori R, Karbassi A, Ashrafi K, Ardestani M, Mehrdadi N, Nabi Bidhendi G-R (2011a) Active and online prediction of BOD5 in river systems using reduced-order support vector machine. Environ Earth Sci 67(1):141-149

Noori R, Karbassi A, Khakpour A, Shahbazbegian M, Badam HMK, Vesali-Naseh M (2011b) Chemometric analysis of surface water quality data: case study of the Gorganrud River Basin, Iran. Environ Model Assess 17(4):411-420

Noori R, Yeh H-D, Abbasi M, Kachoosangi FT, Moazami S (2015) Uncertainty analysis of support vector machine for online prediction of five-day biochemical oxygen demand. J Hydrol 527:833-843

Noori R, Deng Z, Kiaghadi A, Kachoosangi FT (2016) How reliable are ANN, ANFIS, and SVM techniques for predicting longitudinal dispersion coefficient in natural rivers? J Hydraul Eng 142(1):04015039

Parsaie A, Haghiabi A (2015a) Computational modeling of pollution transmission in rivers. Appl Water Sci. doi:10.1007/s13201-0150319-6

Parsaie A, Haghiabi A (2015b) Predicting the longitudinal dispersion coefficient by radial basis function neural network. Model Earth Syst Environ 1(4):1-8

Parsaie A, Haghiabi AH (2015c) Calculating the longitudinal dispersion coefficient in river, case study: Severn River, UK. Int J Sci Res Environ Sci 3(5):0199-0207

Parsaie A, Yonesi H, Najafian S (2015) Predictive modeling of discharge in compound open channel by support vector machine technique. Model Earth Syst Environ 1(1-2):1-6

Singh KP, Basant A, Malik A, Jain G (2009) Artificial neural network modeling of the river water quality-a case study. Ecol Model 220(6):888-895

Wang Z-Y, Lee JW, Melching C (2015) Water quality management. In: Wang Z-Y, Lee JW, Melching C (eds) River dynamics and integrated river management. Springer, Berlin, pp 555-631

WHO (2011) Guidelines for drinking-water quality. WHO Chron 38:104-108

Zare Abyaneh H (2014) Evaluation of multivariate linear regression and artificial neural networks in prediction of water quality parameters. J Environ Health Sci Eng 12(1):1-8

Zarei H, Pourreza Bilondi M (2013) Factor analysis of chemical composition in the Karoon River basin, southwest of Iran. Appl Water Sci 3(4):753-761 